\title{
Quality Practices as a Moderator in Technology Transfer Performance
}

\author{
Sarina, Muhamad Noor (Corresponding author) \\ Faculty of Business Management, Universiti Teknologi MARA \\ 02600 Arau Perlis, Malaysia \\ Tel: 60-4-9882-879 \\ E-mail: sarina@perlis.uitm.edu.my, smnoor95@yahoo.com \\ Rushami, Zien Yusof \\ College of Business, Universiti Utara Malaysia \\ 06010 Sintok Kedah, Malaysia \\ Tel: 60-4-928-4000 \\ E-mail: rzy278@uum.edu.my, rushamizien@yahoo.com \\ Fariza, Hashim \\ College of Business, Universiti Utara Malaysia \\ 06010 Sintok Kedah, Malaysia \\ Tel: 60-4-928-4000Ｅ-mail: fariza@uum.edu.my
}

\begin{abstract}
Absorptive capacity is one of the factors that determines the success of technology transfer. It improves one's ability to assess the current and future needs of firms and leads them to make better choices. At the same time, quality movement in firms also has a similar vision; to make firms move forward in a competitive way. The objective of this paper is twofold. First, was to determine the association between absorptive capacity and technology transfer dimensions. Secondly, this study was conducted to determine the moderating role of firms' quality practices in the relationship between firms' absorptive capacity and technology transfer performance. Data was collected from Malaysian firms through mailed questionnaires. With a response rate of $32 \%$, data was analyzed using multiple hierarchical regression and Chi Square method. The results showed quality process interacts significantly with knowledge diversification and transformative capacity during the integration stage. Moreover, the addition of a moderating variable increases the prediction of technology transfer performances. The result suggests firms' investment in quality practices improves the process of transferred technology.
\end{abstract}

Keywords: Quality practices, Technology transfer, Absorptive capacity, Malaysia

\section{Introduction}

The study on technology transfer covers various disciplines and topics such as the process, the barriers, the opportunities and the modes of technology transfer (Reisman, 2005; Zhao \& Reisman, 1992). However, lack of studies focused on absorptive capacity and quality practices make it deems necessary to study on these aspect. Absorptive capacity ensures that through transferred technology, development, growth and spillover benefits firms and country. At the same time, as quality movement is inherent in many organizations, it should play an important aspect in ensuring the transfer works well. Firms invest in quality programs or activities as it contributes to firms' performance by creating, sustaining and dictating a firm's competitive advantage. Hence, recipient firms should consider the impact of transfer performance with both the absorptive capacity and the quality movement in force.

This paper is organized as follows; after introduction, this paper will present the rationale of this study, followed by literature review, research design, findings and discussion of this study. Finally, it concludes with implications and 
suggestions for future research.

\section{Research rationale}

Technology transfer is not a new phenomenon. Since the 1960s Malaysia has been involved in technology transfer activities when the government began to focus on industrialization aspects. The labor-intensive-export orientation industrialization (L-EOI) period introduced between 1961 and 1980 focused on extensive use of labor in the manufacturing sector to stimulate foreign participation in local firms (Suhaimi \& Yusof, 2006). Since then, there has been a growth of technology transfer activities in the form of foreign direct investment, licensing and technical assistance. The MITI report (2001) and Lai \& Yap (2004) study also suggest that historically, during 1989-2001, foreign technology inflows to Malaysia were mostly for electronics industries using those channels. Global Competitiveness Report (2002) also shows that Malaysia came second after Singapore with a technology transfer index of 1.08 as compared to 1.95 . This data is parallel with findings by Lee \& Tan (2006) who discovered that Malaysia comes second after Singapore in terms of technology transfer.

The study on Malaysia's ability to capitalize on the benefits of technology transfer was conducted by a few authors (Abibullah et al., 1994; Y. W. Lai \& Narayanan, 1997; Narayanan \& Rasiah, 1992; Norlela Ariffin \& Figueiredo, 2004; Zainal, 2004). They focused on many perspectives such as the human resource aspects, general overview of transfer practices and technological capabilities. However, their findings were inconclusive. For example, a study by Norlela Ariffin \& Figueiredo (2004) found that there is a certain level of capabilities that local firms have achieved. Nevertheless, a study by Zaidah et al. (2007) showed that MNCs are reluctant to transfer the key technological knowledge to Malaysia. Furthermore, Suhaimi \& Yusof (2006) indicates that Malaysia was unable to produce indigenous technology. The other study by Jegathesan et al. (1997) and Lall (2002) also suggested that Malaysian workers were unable to adapt and conduct sophisticated repairs due to limited theoretical knowledge which disallow the locals to conduct operation independently from the technology providers. These studies support previous studies by Narayanan \& Wah (1993) and Zainal (2004), which indicate locals are still at a low level of technological activities. Yet, in order to be useful, the real test of transferred technology is on its contribution towards the development of the industry and the country (Ganesan \& Kelsey, 2006).

\section{Literature review}

Absorptive capacity is important in establishing technology transfer activities in firms. In a study by Mowery et al.(1996) and Kneller (2002), it is suggested that absorptive capacity would contribute to firms ability in adopting a particular technology. Madanmohan et al. (2004) suggested that the extent of firms' absorptive capacity will determine their level of participation in the technology transfer process and the type of technology that they can operate efficiently. Meanwhile, studies (Adams \& Lamont, 2003; Garud \& Nayyar, 1994; Zahra \& George, 2000, 2002) had also discussed on transformative capacity, which could enhance absorptive capacity. Thus, the elements of absorptive capacity are not restricted to a firm's ability to identify, assimilate, transform and exploit the external knowledge, it also includes its internal "ability to continually redefine a product portfolio based on technological opportunities created within a firm"(Garud \& Nayyar, 1994). Based on that argument, this study includes them as an absorptive capacity construct.

In addition to firms' absorption capacity, firms' internal factors might contribute in explaining the success of the transferred activities. As future quality-oriented initiatives are affected by firms' routine and practice in quality initiatives (Lenox \& King, 2004), quality practices could explain the level of transferred technology that are being influenced by firms' absorption capacity. Yet, there is limited understanding and empirical evidence on the role of quality practices in strengthening the transfer process. Studies (Elsey \& Fujiwara, 2000; Heinbuch, 1995) on quality practices used quality as the technology that is transferred. The measurement is more on whether the quality process is transferred successfully or encountered difficulties.

In addition, much of the quality study research attempts to address the quality issue only in terms of meeting customers' needs and also in achieving firms' objectives. In contrary to the argument that suggests that if technology is of better quality then it will lead into quality transferred technology, though some studies indicate other directions. Studies by Bennet \& Hongyu (2004) showed that customers' perceptions differ on the quality of the transferred technology while Story \& Loroz (2005), who studied the role of technology and technology congruence on consumers' perceptions, discovered that a cue for quality is seen in both an absolute sense (i.e. higher technology means higher quality) as well as with regard to brand congruity (i.e. brands are more trusted in their production of extensions of similar technology). Whereas, several studies also indicate that the technology transferred must incorporate the aspect of quality. For example, in a study by Quazi \& Bartels (1998) on the application of Total Quality Management(TQM) in firms, TQM were suggested to affect the international technology transfer and intra-firm transfer. Other studies (Correia et al., 2003; Ivarsson \& Alvstam, 2005) showed that assistance from the providers could be beneficial.

Therefore, the objectives of this study are to identify the association between firms' absorptive capacity and the performance of transferred technology and secondly to determine the moderator effect of quality practices on the 
relationship between absorptive capacity and technology transfer performance.

\section{Method}

\subsection{Sample}

This study focused on the Electronic and Electrical manufacturing firms in Malaysia. A list of the company names were obtained from the Directory of Foreign Affiliated Companies in Malaysia (2007) and the Japan Related Companies yearbook 2007 (JETRO). From the population of 525 firms, a sample of 226 (43\%) was solicited. The following steps were used:

A telephone call was made to each firm to confirm their address and the person-in-charge of production so that the letter will arrive to the right person. A production manager or research and development manager or general manager were the people who were expected to answer the questionnaires as they were responsible on the production line and most probably involved in the transfer of technology.

A questionnaire package was mailed to the respective person. The package included a cover letter that explained the study objectives and to request participation, with a questionnaire and a return stamped envelope.

Upon receiving the completed questionnaire, a token of appreciation was mailed to each respondent.

A reminder letter was sent to the non-respondents with a new completed questionnaire package. A grace period of one month was allowed between the first batch of questionnaires, and the first, second and third reminder.

The response rate was 32\% from the sample size. The questionnaires were administered from March to September 2008. 35 questionnaires were received between March and June 2008. Besides the reminder letter, other follow-up actions were undertaken such as telephone calls and also personal visits to the factories in order to increase the response rate. The actions resulted in receiving another 38 responses.

\subsection{Questionnaire design}

There were few variables in this study. Questions for technology transfer performance variables were adapted from Szulanski (1996). There were four sections, namely the initiation stage, the implementation stage, the ramp-up stage and the integration stage. These four sections covered the activities that lead to transfer of technology where it includes the process of choosing the technology and the problems that are associated with the transfer until the transferred technology was materialized and satisfactorily done. The initiation stage included the activities that make firms decide to be involved in receiving technology; the implementation stage was when firms took action to make the transfer real; the ramp-up stage was when firms handled any problems and issues related to the transferred activities and the integration stage was on evaluation of the transferred technology. There were 20 questions related to the technology transfer dimension.

For the absorptive capacity construct, the dimensions used were adapted from Nieto \& Quevedo (2005). The section consisted of four sections, which were links between firms and its surroundings, level of knowledge and experience, diversification of knowledge structure and strategic posture. These terms were to reflect the four dimensions of absorptive capacity namely, the ability to identify, assimilate, transform and exploit the external knowledge as discussed in previous literatures. As previous literature has demonstrated that transformative capacity would concurrently enhance absorptive capacity, allowing their dimensions were also considered here. Eight questions from Garud \& Nayyar (1994) were adapted making a total of 31 questions under absorptive capacity dimensions.

The questions on quality practices were adapted from two parts, namely quality training and quality tools and process. The purpose of using training as an element in the quality practices is because it is mostly associated with TQM performance consequences (Powell, 1995) and it enhances understanding of quality movements in organizations (Elsey \& Fujiwara, 2000). Only through training are the staffs able to appreciate quality practices in the organization. In addition, as process quality management also includes improvement, quality control and evaluation practices in an organization, the use of tools and techniques, and preventive maintenance were considered. Eight questions were included under the quality process construct. Hence, there were a total of 59 questions in the questionnaires, excluding four questions on firm demographic factors such as the firm ownership, firm size, ways firms received technology and their revenues.

Even though sample size was less than 100, factor analysis is permissible. Moreover, sample size is not important especially with high communalities (MacCallum et al., 1996; MacCallum et al., 2001). Therefore, the questions were factor analyzed using several criteria. There should be at least three variables for each factor as suggested by Jae-O Kim \& Mueller (1978). The factor loading should be more than 0.63 following Comrey \& Lee (1992) as mentioned in Tabachnick \& Fidel (Tabachnick \& Fidell, 2007) who suggested that loading of 0.71 was considered excellent, 0.63 was very good, 0.45 as fair and 0.32 as poor. Thus, if the loading for each item was less than 0.63 , the item was deleted from the construct. Moreover, in determining the factorability of the dimensions, the Bartlett's test of sphericity has to be significant and the Kaiser-Meyer-Olkin Measure of sampling adequacy has to be more than 0.50 in order to be acceptable (Hair et al., 1998). Result of factor analysis shown in table 1.0 produced two acceptable dimensions under 
technology transfer performance, three acceptable dimensions under absorptive capacity and one dimension for quality practices. Table 1.0 shows the results.

Insert Table 1 here

\section{Results and discussion}

The data was analyzed using SPSS version 13.0. The majority of the respondents were male (85\%) holding positions such as manager $(52 \%)$, senior managers $(21 \%)$, and engineers (14\%). In terms of number of employees the firms had, $43.8 \%$ had employees between 101 to $500,26 \%$ of the firms had employees between 1001 to $5000,20.5 \%$ had employees between 501 to $1000,5.5 \%$ of the firms employed 100 or less employees and only $2.7 \%$ had employees more than 5000 . $69.9 \%$ of the firms were owned fully by foreign participation. Table 2.0 shows the details.

\section{Insert Table 2 here}

A majority of the firms (82.2\%) received technology from training provided by their parent company, while $57.5 \%$ received transfer of technology through the purchase of machinery and equipment. 31 firms $(42.5 \%)$ conducted contract manufacturing or OEM, 22 firms (30.1\%) were involved in some form of technology transfer agreement, 20 firms (27.4\%) received technology through conducting sub-contract works and only 10 firms (13.7\%) received technology through specialist attachment. There were also firms that received technology from their client company. In terms of technology transfer channel, $41.7 \%$ were involved in technological assistance, $34.3 \%$ were engaged in management and supporting agreements and $26.4 \%$ were under licensing, trademark and patent. The findings are similar to Lai \& Yap (2004) study who found that technical assistance, licensing, trademarks and patents are the major channel of technology transfer to Malaysian E\&E firms.

A six-point Likert scale was used on the questionnaire with 1 indicating strongly disagree and 6 strongly agree. From the descriptive statistics, the mean for technology transfer stage was 4.53 with a minimum scale of 2 and a maximum scale of 4. This indicates that on average the respondents are somewhat agreed on the process of technology transfer stages where the highest level of agreement was somewhat agree, as denoted by scale 4. Looking into details for each of the technology transfer stages, for the implementation stage, the highest scale respondents chose was agree (5) with a mean of 4.70 while for the integration stage, the highest score was 6 (strongly agree). Thus, most of the firms concurred with the technology transfer stages that they are involved in.

Meanwhile, for absorptive capacity, the mean was 4.53 (agree) with a minimum scale of 3 (somewhat disagree) and a maximum scale of 5 (agree). Both knowledge diversification and transformative capacity had a minimum scale of 1 (strongly disagree) with a maximum scale of 5 (agree) and 6 (strongly agree), respectively. For strategic posture, the mean was higher at 5.54 (strongly agree) as compared to knowledge diversification (4.28) and transformative capacity (3.78). These indicate most firms concentrated on strategic issues and less focused on transformative capacity. This situation might reduce firms' ability for future development at faster rate. The mean for quality process was 4.82 (agree) indicating quality practices are inherent in majority of the firms. Overall, the mean for the major variables was between 3.78 and 5.54. Table 3.0 shows the mean and standard deviation for all the variables.

\section{Insert Table 3 here}

The Pearson correlation showed there was an association between absorptive capacity and technology transfer performance. Even though none of the absorptive capacity dimensions were found significant with the implementation stage, transformative capacity and knowledge diversification were significant in both technology transfer performance composite and the integration stage The strength between knowledge diversification and the integration stage was moderate (0.25). The same goes for the association between transformative capacity and the integration stage $(\mathrm{r}=0.29)$. The results that showed absorptive capacity does not have any relationship with implementation stage is worrisome as lacking in such ability at the initial stage of technology performance will lead to future in-capabilities to perform independently. The situation can be interpreted in such a way whereby most of firms that are at implementation stage could not proceed to integration stage. This is indicative of lack of technological capabilities as mentioned by few authors such as Jegathesan et al. (1997), Lall (2002), Narayanan \& Wah (1993) and Zainal (2004). The presence of foreign participation in the firms could contribute to the phenomena especially for those that have majority foreign-controlled investment. The moderate association between knowledge diversification and transformative capacity with integration stage indicates both factors are important to evaluate the transferred technology. Thus, firms should focus in developing various knowledge and invest in shelved technologies.

As the purpose of this paper was to determine quality practices as the moderator, steps suggested by Sharma, Durand \& Gur-Arie (1981) were used. The data was analyzed using multiple regression analysis (MRA). Several steps were involved. The data was regressed in three blocks. The first blocks included only the predictors, the second block was on the moderator variable and the third block included the interaction between the moderator and each of the predictors. Table 4.0 portrays the MRA on absorptive capacity dimensions and implementation stage using quality process as the moderator. The F value under step 1, step 2 and step 3 in Table 4.0 indicates that the quality practice has no moderating 
effect on absorptive capacity dimensions or the implementation stage. Furthermore, all the Beta coefficients were not significant. Hence, further analysis was not required.

Insert Table 4 here

A similar step was done on the integration stage. However, for the integration stage in Table 5.0, different results were discovered. Here, the quality process has a moderating effect with $\beta=0.423$. The interaction between quality process and knowledge diversification is significant at a $90 \%$ confidence level while the interaction between strategic posture and quality process is significant at a $95 \%$ confidence level with a $\beta$ of 16.5 and 30.5 respectively. There is a significant F change of 0.000 (step 1 and step 2) and 0.003 (step 3). The $\mathrm{R}^{2}$ increased from $33 \%$ under step 1 to $49 \%$ in step 2 and $61 \%$ in step 3. As there was a significant change in $\mathrm{R}^{2}$, there was a significant moderator effect on the absorptive capacity-technology transfer relationship.

Insert Table 5 here

Since the interaction between the moderator and predictors was significant, a correlation test was required to ascertain the type of moderators of the quality process in the relationship between the criterion and the predictor. A correlation between quality process and integration stage showed a significant correlation with an $\mathrm{r}$ of 0.544 at $\mathrm{p}<=0.001$ significance level. Hence, the quality process was a quasi-moderator. Further explanation on the moderator variable was achieved through the plotted graph in Figure 1.0. The plotted graph showed a positive correlation between knowledge diversification and the integration stage in firms with high quality processes. However, firms that have low quality processes had a low integration stage that increased slowly with the increase in knowledge diversification. Similarly, firms that have high quality processes also increased their ability to integrate technology with the increase in strategic posture. However, even though the strategic posture was high, the integration stage reduced when the quality process was low. In other words, the relationship between strategic posture and the integration process is negatively correlated in firms with low quality processes.

Insert Figure 1 here

The results of this study were encouraging. Even though the Pearson correlation indicated an association between several dimensions of absorptive capacity and the integration stage only, it showed that quality process was important in improving the transfer stage. Through the graphs, high quality process was beneficial in the integration stage given high knowledge diversification and high strategic posture. This means that investment in the quality process will help in the integration of technology. It supports the existence of firm's knowledge diversification and their strategic posture. Hence, firm's investment in quality process should be encouraged as it promotes the technology transfer process.

The end result of transferred technology is important as it will have a positive effect on the firm and the country. There are implications that many implementations of technology decisions were made by the parent company as the majority of the respondents were foreign-controlled firms. In previous studies (Hobday, 1996; Mohd Nazari, 1999), local competencies were regarded as vital but there was evidence that managerial decision-making was somewhat restricted. Thus it supports study by Sinani \& Meyer (2004) who concluded that foreign presence affects spill-over. This might explain the lack of relationship between absorptive capacity and the implementation stage. . Even though no moderator effect was found during the implementation stage, the quality practice became a quasi moderator during the integration stage. This suggests that firms should continue to invest in quality practices in order to enhance the technology transfer process.

\section{Conclusion}

Findings of this study contribute to the management discipline in two areas. First, it indicates that transformative capacity is part of absorptive capacity dimension as discovered under factor analysis. Second, it integrates the role of absorptive capacity and the moderator effect of quality process to technology transfer. The managers should build-up the absorptive capacity aspects such as knowledge diversification, strategic posture and transformative capacity. By doing so, the firms could increase its absorption capacity on the transferred technology. This will ultimately increase the indigenous capabilities which lead to more innovation and spillover.

The findings present new empirical results that support the building of absorptive capacity and quality process in firms. Hence, firms need to pay attention on absorptive capacity from the initial stage of technology transfer which is during the implementation stage. This stage will help the firms to benefit from the transferred technology as it charts the journey forward. Ignoring absorptive capacity at this level would impede further success in recipients firms to become independent from the providers. As the goal of technology transfer is to obtain the technology that will eventually enhance its development, firms with high absorptive capacity from the early stage of technology transfer would lead to better capabilities. Simultaneously, when firms invest in quality process, it benefits more from the transferred technology. Thus there is more reason for firms to invest in quality process.

Since this study focused on E\&E firms with a limited sample size, further studies could be done on all manufacturing 
firms with regard to the quality practices effect on technology transfer performance. Perhaps a comparison with those that practice quality and those who do not could also be carried out. This will produce more insights into achieving better transferred technology.

\section{References}

Abibullah Haji Samsudin, Morshidi Sirat, \& Kamarulazizi Ibrahim. (1994). Pemindahan teknologi dalam industri elektronik di Malaysia. Kuala Lumpur: Dewan Bahasa Pustaka.

Adams, G. L., \& Lamont, B. T. (2003). Knowledge management systems and developing sustainable competitive advantage. Journal of Knowledge Management, 7(2), 142-154.

Bennett, D., \& Hongyu, Z. (2004). International technology transfer: perceptions and reality of quality and reliability. Journal of Manufacturing Technology Management, 15(5), 410-415.

Correia, E., Lisboa, J., \& Yasin, M. (2003). The effectiveness of quality efforts in the Portuguese business culture: An empirical investigation. Cross cultural management, 10(2), 24-36.

Elsey, B., \& Fujiwara, A. (2000). Kaizen and technology transfer instructors as work-based learning facilitators in overseas transplants: A case study. Journal of Workplace Learning, 12(8), 333-341.

Ganesan, S., \& Kelsey, J. (2006). Technology transfer: international collaboration in Sri Lanka. Construction Management and Economics, 24, 743-753.

Garud, R., \& Nayyar, P. R. (1994). Transformative capacity: Continual structuring by inter-temporal technology transfer. Strategic Management Journal, 15, 365-385.

Hair, J. F., Anderson, R. E., Tatham, R. L., \& Black, W. C. (1998). Multivariate data analysis (5th ed.). New Jersey: Prentice-Hall International Inc.

Heinbuch, S. E. (1995). A case of successful technology transfer to health care. Journal of Management in Medicine, 9(2), 48-56.

Hobday, M. (1996). Innovation in South-East Asia: lessons for Europe? Management Decision, 34(9), 71-81.

Ivarsson, I., \& Alvstam, C. G. (2005). Technology transfer from TNCs to local suppliers in developing countries: A study of AB Volvo's truck and bus plants in Brazil, China, India and Mexico. World Development, 33(8), 1325-1344.

Jae-On Kim, \& Mueller, C. W. (1978). Factor Analysis-Statistical Methods and Practical Issues (Vol. 07-014). London: SAGE Publications Ltd.

Jegathesan, J., Gunasekaran, A., \& Muthaly, S. (1997). Technology development and transfer: Experiences from Malaysia. International Journal of Technology Management, 13(2), 196-214.

Kneller, R. (2002). Frontier technology, absorptive capacity and distance: The University of Nottingham.

Lai, M.-C., \& Yap, S.-F. (2004). Technology development in Malaysia and the Newly Industrializing Economies: A Comparative analysis. Asia-Pacific Development Journal, 11(2), 53-78.

Lai, Y. W., \& Narayanan, S. (1997). The quest for technological competence via MNCs: A Malaysian case study. Asian Economic Journal, 11(4), 407 -422.

Lall, S. (2002). FDI and development. Research issues in the emerging context. In B. Bora (Ed.), Foreign Direct Investment. Research Issues (pp. 325-345). London: Routledge.

Lee, H. H., \& Tan, H. B. (2006). Technology Transfer, FDI and Economic Growth in the ASEAN Region. Journal of the Asia Pacific Economy, 11(4), 394-410.

Lenox, M., \& King, A. (2004). Prospects for developing absorptive capacity through internal information provision. Strategic Management Journal, 25, 331-345.

MacCallum, R. C., Browne, M. W., \& Sugawara, H. M. (1996). Power analysis and determination of sample size for covariance structure modeling. Psychological Methods, 1(2), 130-149.

MacCallum, R. C., Widaman, K. F., Preacher, K. J., \& Hong, S. (2001). Sample size in factor analysis: The role of model error. Multivariate Behavioral Research, 36(4), 611-637.

Madanmohan, T. R., Kumar, U., \& Kumar, V. (2004). Import-led technological capability: A comparative analysis of Indian and Indonesian manufacturing firms. Technovation, 24, 979-993.

Mohd Nazari, I. (1999). Foreign firms and national technological upgrading: The Electronics industry in Malaysia. In K. S. Jomo, G. Felker \& R. Rasiah (Eds.), Industrial Technology Development in Malaysia (pp. 21-37). London and New York: Routledge.

Mowery, D. C., Oxley, J. E., \& Silverman, B. S. (1996). Strategic alliances and inter-firm knowledge transfer. 
Strategic Management Journal, 17(Winter Special Issue), 77-91.

Narayanan, S., \& Lai, Y. W. (1993). Human resource constraints on technology transfer: An empirical analysis of the electronics and electrical sector in Penang, Malaysia. The Singapore Economic Review, 38(2), 155-165.

Narayanan, S., \& Rasiah, R. (1992). Malaysian Electronics: The changing prospects for employment and restructuring. Development and Change, 23(4), 75-99.

Nieto, M., \& Quevedo, P. (2005). Absorptive capacity, technological opportunity, knowledge spillovers and innovative effort. Technovation, 25, 1141-1157.

Norlela Ariffin, \& Figueiredo, P. N. (2004). Internalization of innovative capabilities: Counter evidence from the electronics industry in Malaysia and Brazil. Oxford Development Studies, 32(4), 559-583.

Powell, T. C. (1995). Total Quality Management as competitive advantage: A review and empirical study. Strategic Management Journal, 16(1), 15-37.

Quazi, H. A., \& Bartels, F. L. (1998). Application of TQM principles in the international technology transfer process of industrial production plants. British Journal of Management, 9, 289-300.

Reisman, A. (2005). Transfer of technologies: A cross taxonomy. The International Journal of Management Science, 33, 189-202.

Sharma, S., Durand, R. M., \& Gur-Arie, O. (1981). Identification and analysis of moderator variables. Journal of Marketing Research, 18(3), 291-300.

Sinani, E., \& Meyer, K. E. (2004). Spillover of technology transfer from FDI: The case of Estonia. Journal of Comparative Economics, 32(3), 445-466.

Story, J., \& Loroz, P. S. (2005). Technological congruence and perceived quality of brand extensions. Journal of Product and Brand Management, 14(7), 438-447.

Suhaimi Mhd Sarif, \& Yusof Ismail (2006). The search for indigenous technology within Malaysian economic policies. Journal of Technology Management and Entrepreneurship, 5(2), 71-87.

Szulanski, G. (1996). Exploring internal stickiness: Impediments to the transfer of best practice within the firm. Strategic Management Journal, 17(Winter Special Issue), 27-43.

Tabachnick, B. G., \& Fidell, L. S. (2007). Using Multivariate Statistics (5 ed.). Boston Pearson.

Zahra, S. A., \& George, G. (2000). Absorptive capacity: A review and re-conceptualization. Paper presented at the Academy of Management Proceedings, 1-6.

Zahra, S. A., \& George, G. (2002). Absorptive capacity: A review, re-conceptualization and extension. Academy of Management Review, 27(2), 185-203.

Zaidah, M., Md. Zabid, A. R., \& Murali, S. (2007). Strategic roles of foreign multinational subsidiaries in Malaysia. International Journal Management and Decision Making, 8(2/3/4), 268-289.

Zainal, A. S. (2004, 3-7 April). Technology transfer and the roles of firm-host government coordination: An empirical analysis based on Japanese-affiliated manufacturing firms in Malaysia. Paper presented at the IAMOT 2004, Washington D.C.

Zhao, L., \& Reisman, A. (1992). Toward meta research on technology transfer. IEEE Transactions on Engineering Management, 39(1), 13-21. 
Table 1. The dimensions discovered before and after factor analysis

\begin{tabular}{|l|c|}
\hline Before factor analysis & After factor analysis \\
\hline Absorptive capacity & Absorptive capacity \\
Ability to identify external knowledge & Knowledge diversification \\
Ability to assimilate & Transformative capacity \\
Knowledge diversification & \\
Firms strategic posture & \\
Transformative capacity & Technology transfer performance \\
Technology transfer performance & Integration stage \\
Initiation stage & \\
Implementation stage & \\
Ramp-up stage & \\
Integration stage & Quality Practices \\
Quality Practices & Quality process \\
Quality training & \\
Process Management & \\
\hline
\end{tabular}

Table 2. Demographic data on the respondents

\begin{tabular}{|c|c|c|}
\hline Variable & Frequency $(n=73)$ & Percent (Total 100\%) \\
\hline \multicolumn{3}{|l|}{ Gender: } \\
\hline Male & 62 & 85 \\
\hline Female & 11 & 17 \\
\hline \multicolumn{3}{|l|}{ Position held: } \\
\hline Director & 2 & 3 \\
\hline Senior Manager & 15 & 21 \\
\hline Manager & 38 & 52 \\
\hline Assistant Manager & 8 & 11 \\
\hline Executives/Engineers & 10 & 14 \\
\hline \multicolumn{3}{|l|}{ Number of employees: } \\
\hline 100 or less & 4 & 5.5 \\
\hline $101-500$ & 32 & 43.8 \\
\hline $501-1000$ & 15 & 20.5 \\
\hline $1001-5000$ & 19 & 26 \\
\hline 5001 and above & 2 & 2.7 \\
\hline \multicolumn{3}{|l|}{ Types of ownership: } \\
\hline Fully local & 6 & 8.2 \\
\hline Majority foreign & 10 & 13.7 \\
\hline Majority local & 6 & 8.2 \\
\hline Fully foreign & 51 & 69.9 \\
\hline
\end{tabular}


Table 3. The mean and standard deviation of major variables

\begin{tabular}{|c|c|}
\hline Construct & $\begin{array}{l}\text { Mean } \\
\text { Standard Deviation }\end{array}$ \\
\hline $\begin{array}{l}\text { Absorptive Capacity } \\
\text { Knowledge diversification } \\
\text { Strategic posture } \\
\text { Transformative capacity }\end{array}$ & $\begin{array}{l}4.53 \\
0.54 \\
4.28 \\
0.80 \\
5.54 \\
0.51 \\
3.78 \\
0.95\end{array}$ \\
\hline $\begin{array}{l}\text { Technology transfer stage } \\
\text { Implementation stage } \\
\text { Integration stage }\end{array}$ & $\begin{array}{l}4.53 \\
0.63 \\
4.36 \\
0.97 \\
4.70 \\
0.70\end{array}$ \\
\hline Quality practice & $\begin{array}{l}4.82 \\
0.75\end{array}$ \\
\hline
\end{tabular}

Table 4. The moderating effect of quality process on the relationship between absorptive capacity dimensions and the implementation stage

\begin{tabular}{|c|c|c|c|}
\hline \multirow[b]{2}{*}{ Variable } & \multicolumn{3}{|c|}{ Standardized Beta } \\
\hline & $\begin{array}{c}\text { Step 1 } \\
\text { Without } \\
\text { interaction }\end{array}$ & Step 2 & $\begin{array}{c}\text { Step 3 } \\
\text { With } \\
\text { interaction }\end{array}$ \\
\hline Knowledge Diversification(KD) & -0.61 & -0.057 & 0.023 \\
\hline Strategic Posture (SP) & -0.347 & $-0.356^{* *}$ & $-0.370 * *$ \\
\hline Transformative Capacity (TC) & 0.047 & 0.004 & 0.051 \\
\hline Quality Process (Qp) & & 0.167 & 0.041 \\
\hline $\mathrm{KD} \times \mathrm{Qp}$ & & & -0.310 \\
\hline SP x Qp & & & 0.180 \\
\hline $\mathrm{TC} \times \mathrm{Qp}$ & & & -0.027 \\
\hline $\mathrm{R}^{2}$ & 0.150 & 0.176 & 0.241 \\
\hline Adjusted $\mathrm{R}^{2}$ & 0.058 & 0.069 & 0.093 \\
\hline $\mathrm{R}^{2}$ Change & 2.513 & 1.661 & 1.473 \\
\hline Significant F Change & 0.068 & 0.203 & 0.233 \\
\hline
\end{tabular}

$* * *$ - Significant at 0.01

** - Significant at 0.05 
Table 5. The moderating effect of quality process on the relationship between absorptive capacity dimensions and integration stage

\begin{tabular}{|l|c|c|c|}
\hline \multirow{2}{*}{ Variable } & \multicolumn{2}{c|}{ Standardized Beta } \\
\cline { 2 - 4 } & $\begin{array}{c}\text { Step 1 } \\
\text { Without } \\
\text { interaction }\end{array}$ & Step 2 & $\begin{array}{c}\text { Step 3 } \\
\text { With } \\
\text { interaction }\end{array}$ \\
\hline Knowledge Diversification(KD) & $0.524^{* * *}$ & 0.416 & $0.401^{* * *}$ \\
Strategic Posture (SP) & 0.116 & 0.103 & 0.102 \\
Transformative Capacity (TC) & 0.045 & 0.013 & -0.115 \\
Quality Process (Qp) & & $0.423^{* * *}$ & 0.225 \\
KD x Qp & & & $0.165^{*}$ \\
SP x Qp & & & $0.305^{* *}$ \\
TC x Qp & 0.326 & 0.488 & 0.166 \\
\hline $\mathrm{R}^{2}$ & 0.250 & 0.419 & 0.612 \\
Adjusted R & & 16.406 & 0.532 \\
$\mathrm{R}^{2}$ Change & 8.183 & 0.000 & 5.202 \\
Significant F Change & 0.000 & & 0.003 \\
& & & \\
\hline
\end{tabular}

*** - Significant at 0.01

** $\quad$ - Significant at 0.05
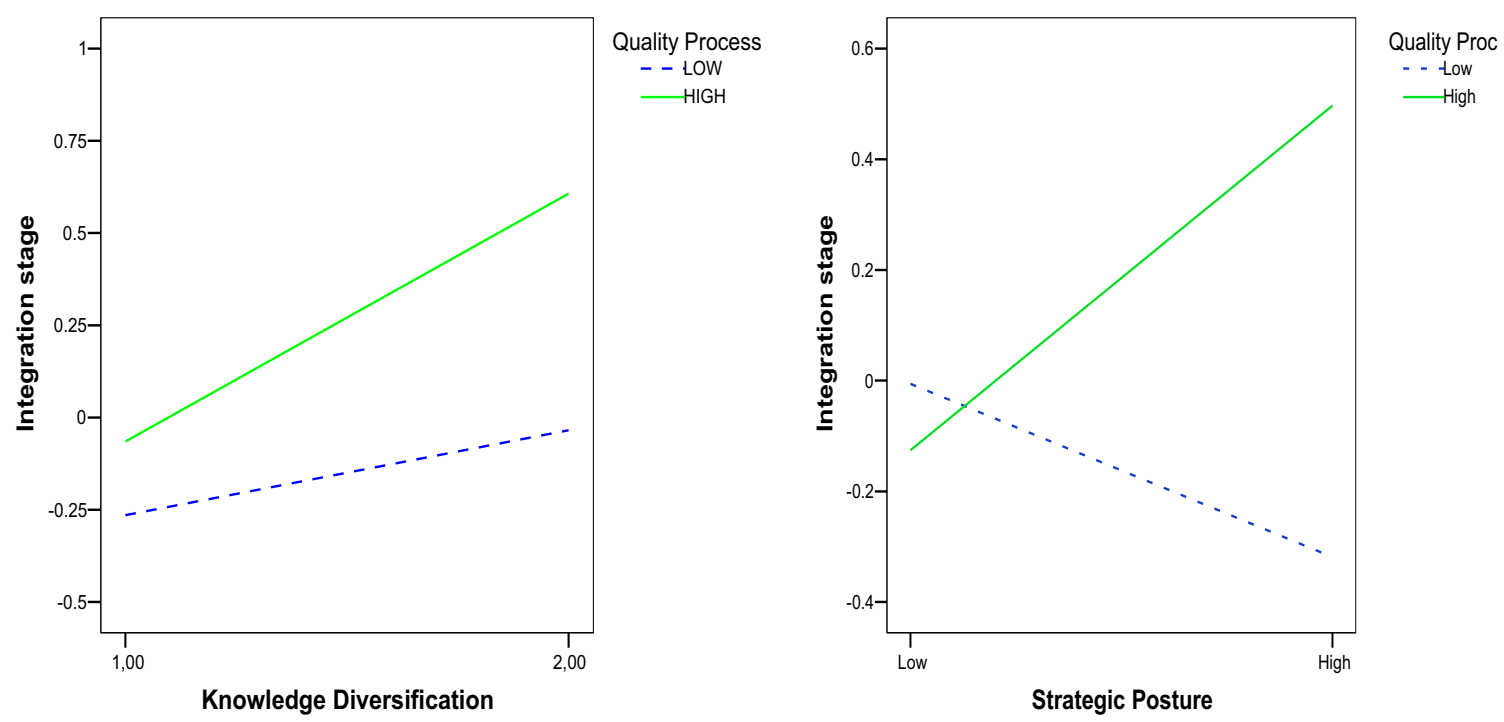

Figure 1. The relationship between (a) knowledge diversification and integration stage and (b) strategic posture and the integration stage with quality process as the moderator 